Kredo 3 (2020)
KREDO: Jurnal Ilmiah Bahasa dan Sastra
Terakreditasi Sinta 4 berdasarkan Keputusan Direktorat
Jenderal Penguatan Riset dan Pengembangan,
Kementerian Riset, Teknologi dan Pendidikan Tinggi
Republik Indonesia
Nomor: 23/E/KPT/2019. 08 Agustus 2019
https://jurnal.umk.ac.id/index.php/kredo/index

\title{
PENGEMBANGAN BAHAN AJAR BERBASIS MODUL INTERAKTIF BAGI PEMELAJAR BIPA TINGKAT A1
}

\author{
Dyah Ayu Fajar Utami ${ }^{\bowtie}$ \& Laili Etika Rahmawati \\ a310160066@student.ums.ac.id, laili.rahmawati@ums.ac.id
}

Prodi Pendidikan Bahasa dan Sastra Indonesia, Fakultas Keguruan dan Ilmu Pendidikan

Universitas Muhammadiyah Surakarta, Indonesia

\section{Info Artikel \\ Sejarah Artikel \\ Diterima 30 April \\ 2020 \\ Disetujui 15 Mei \\ 2020 \\ Dipublikasikan 20 \\ Mei 2020}

Keywords

bipa. bipa

learning, teaching

materials,

interactive

modules

\section{Kata Kunci}

bipa,

pembelajaran

bipa, bahan ajar, modul interaktif.
:

\section{Abstract}

The Indonesian language program for foreign speakers (BIPA) is an interesting study to pursue. This is evidenced by the many institutions or universities that conduct BIPA. In order to provide quality BIPA education services, the availability of abundant teaching materials is needed. This research utilizes the method of $R \& D$ or research and development. This study was designed with the stage of extracting potentials and problems, collecting related data, designing instructional materials. The purpose of this study was to develop a learning module design for A1 level BIPA learners (beginners). Based on the research that has been done, the authors found that: (1) the development of module-based teaching materials is needed by learners considering that only one textbook is used, another addition is needed to enrich learning resources and the discrepancy of content in textbooks with characteristics (2) product development in the form an interactive module

: for BIPA learners entitled "Love Indonesian Language A1" has been carried out by adjusting the needs of learners' perceptions and the characteristics of adult learners. The implication of this research is that the developed module can be used as a reference for BIPA teaching materials.

\section{Abstrak}

Program bahasa Indonesia bagi penutur asing (BIPA) tengah menjadi kajian yang menarik untuk ditekuni. Hal tersebut dibuktikan dengan banyaknya lembaga atau universitas yang menyelenggarakan BIPA. Dalam rangka memberikan pelayanan pendidikan BIPA yang : berkualitas, diperlukan ketersedian bahan ajar yang melimpah. Riset ini memanfaatkan metode R \& $\mathrm{D}$ atau penelitian dan pengembangan. Penelitian ini dirancang dengan tahap penggalian potensi dan masalah, mengumpulkan data terkait, membuat rancangan bahan ajar, Tujuan dari penelitian ini adalah untuk mengembangkan desain modul pembelajaran untuk pemelajar BIPA level A1 (pemula). Berdasarkan riset yang telah dilakukan, penulis menemukan bahwa: (1) pengembangan bahan ajar berbasis modul dibutuhkan oleh pembelajar mengingat buku ajar yang digunakan hanya satu, perlu tambahan lain untuk memperkaya sumber belajar dan ketidaksesuaian konten dalam buku ajar dengan karakteristik (2) pengembangan produk berupa modul interaktif bagi pemelajar BIPA bertajuk "Gemar Berbahasa Indonesia A1" telah dilakukan dengan menyesuaikan kebutuhan dari persepsi pembelajar dan karakteristik pemelajar dewasa. Implikasi dari riset ini adalah modul yang dikembangan dapat dijadikan salah satu referensi bahan ajar pengajaran BIPA. 


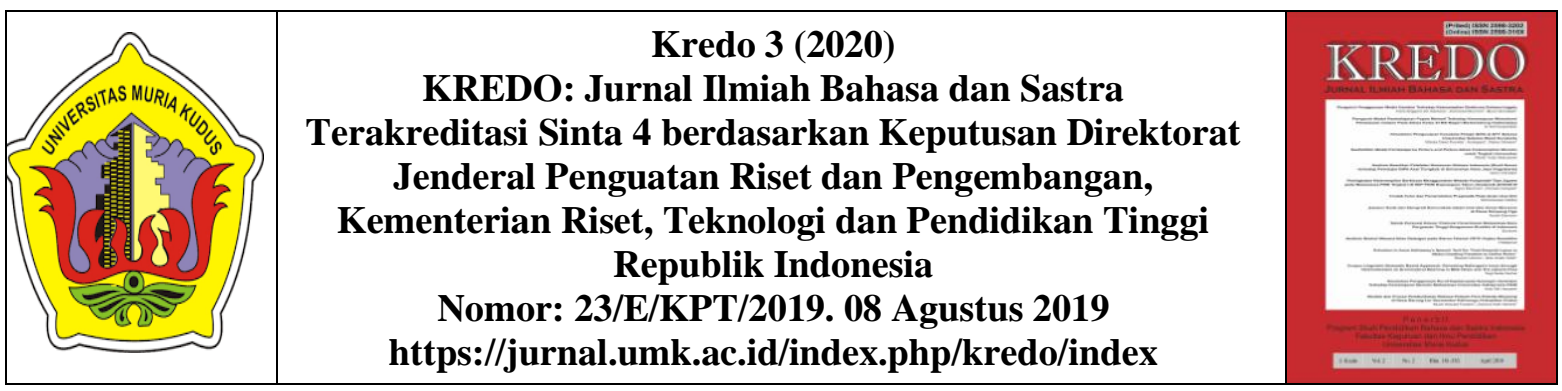

\section{PENDAHULUAN}

Minat untuk belajar BIPA makin menunjukkan peningkatan yang positif. Perkembangan ini tidak hanya pada pembelajaran BIPA di dalam negeri, tetapi juga di luar negeri (Purwiyanti, 2017:160). Kusmiatun (2016:10) menyatakan tidak hanya di dalam negeri melainkan juga di luar negeri program BIPA dilaksanakan. Merujuk pada data tahun 2012 di laman badan pengembangan dan pembinaan bahasa bahwa program BIPA telah diimplementasikan di dalam negeri melalui 45 lembaga. Lebih dari 130 lembaga dari 36 negara di dunia telah menyelenggarakan pengajaran BIPA dengan layanan pusat kebudayaan asing, KBRI, dan lembaga kursus (Lubna, 2017:83).

Kurangnya ketersediaan bahan ajar BIPA yang ada di pasaran, tidak mendukung besarnya atensi pemelajar asing. Oleh karena itu, diperlukan pengembangan bahan ajar bagi pemelajar BIPA sebagai penyeimbang besarnya minat bangsa asing untuk mempelajari bahasa Indonesia (Ulumuddin, 2014:15). Peningkatan minat tersebut harus diimbangi pula dengan ragam bahan ajar yang berkualitas. Arsanti (2018:71) menyampaikan bahwa kurangnya bahan ajar nantinya akan berpengarung kepada kualitas pembelajaran dan perkuliahan. Pernyataan tersebut senada dengan pendapat (Prasetyo, 2015:5) yang berbunyi terbatasnya bahan ajar adalah masalah penting dalam pembelajaran BIPA Pada risetnya ia menuturkan bahwa pengajar menghadapi kesulitan ketika memilah bahan ajar mana yang tepat untuk disajikan dalam pembelajaran. Mengingat tidak semua bahan ajar dapat membantu pemelajar dalam rangka mencapai kompetensi yang telah ditentukan. Selanjutnya, mengingat keputusan kongres Bahasa Indonesia VI tahun 1993 di Jakarta, yang menerangkan bahwa perlu dilakukannya pengembangan materi BIPA yang berbeda dengan pembelajaran bahasa Indonesia untuk orang Indonesia.

Setiap tahun, siswa asing yang mendaftar di sekolah atau universitas di Indonesia sangat banyak dan cenderung meningkat (Kusmiatun, 2017:198). Tren berkembangnya minat untuk mempelajari bahasa Indonesia secara formal adalah sebuah peluang sekaligus tantangan. Maksud peluang adalah aktivitas diplomasi kebahasaan dan kebudayaan akan mendapat angin segar dan semakin mudah. Wiratsih (2019:242) menjabarkan bahwa BIPA ialah alat diplomasi, yang mampu memperkuat eksistensi bangsa Indonesia. Berkat BIPA, negara di belahan dunia lainnya dapat mengenal Indonesia dan menarik mereka untuk membuat kerjasama atau berhubungan baik. Di sisi lain, peningkatan kualitas pembelajaran BIPA itu sendiri menjadi sebuah tantangan. Tantangan BIPA tersebut secara luas akan berkaitan erat dengan wacana internasionalisasi bahasa Indonesia (Yahya, 2018:53).

Sebuah gagasan besar untuk menginternasionalisasikan bahasa Indonesia nyatanya membutuh dukungan dari berbagai kalangan. BIPA adalah salah satu ujung tombak dari pergerakan internasionalisasi bahasa Indonesia. Upaya strategis yang dapat dilakukan secara internal adalah meningkatkan mutu pengajaran BIPA itu sendiri. Pengajaran BIPA harus lebih diperhatikan dengan lebih baik. Program BIPA perlu ditangani dengan jeli, 


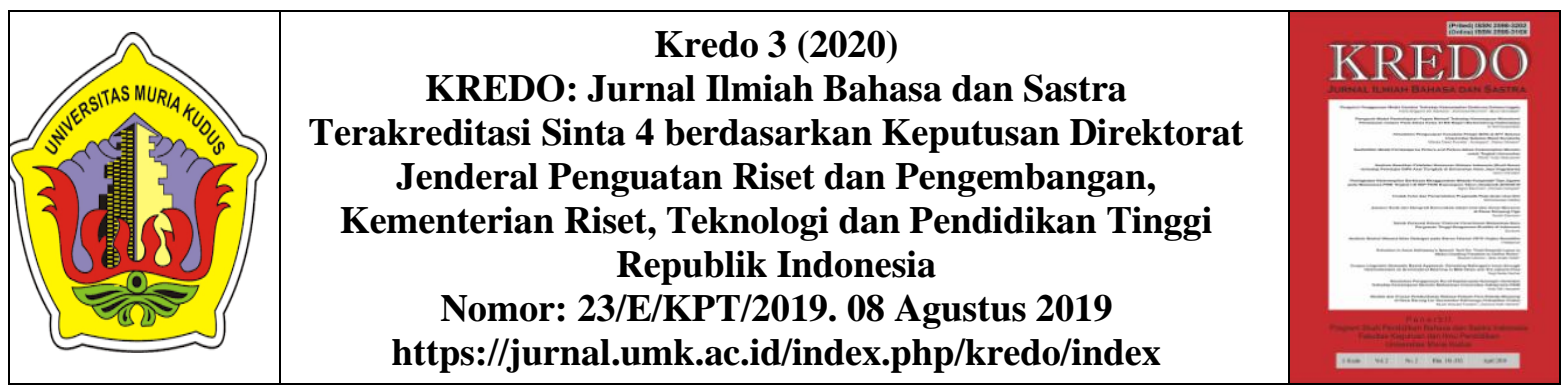

perbaikan standarisasi, penyiapan pengajar berkualitas, pengembangan media dan bahan ajar.

Masalah lain yang muncul dalam pembelajaran bahasa tertentu sebagai bahasa asing dipengaruhi oleh perbedaan linguistik dan sosiokultural dari bahasa pertamanya. Ide penyelenggaraan pendidikan berbasis elektronik atau web adalah salah satu opsi yang dapat dipilih untuk mengakomodasi keberagaman mahasiswa asing atau pemelajar BIPA. Selain itu, gagasan tersebut diharapkan mampu memecahkan batasan-batasan pendidikan tradisional seperti waktu, pengaturan dan staf pengajar, menjadikan penyelenggaraan pendidikan lebih fleksibel (Celik, 2010:1976).

Pengembangan bahan ajar yang berbasis elektronik dan interaktif dibutuhkan dalam rangka memenuhi tantangan yang kian hari kian dinamis. Perubahan zaman yang tidak sistemik dan konsisten, mengharuskan guru, profesor, peneliti, dan pembuat kebijakan pendidikan untuk terus berinovasi. Pernyataan tersebut didukung oleh Kristanto (2017:10) yang berpendapat jika di era globalisasi, melalui kecanggihan teknologi, memungkinkan siswa dapat belajar dengan lebih efektif dan efisien. Inovasi baik pada teori dan praktik pengajaran dan pembelajaran, serta semua aspek lain yang mendukung untuk memastikan persiapan kualitas siswa atau pembelajar untuk kehidupan dan pekerjaan masa mendatang (Serdyukov, 2017:4). Perubahan zaman pun dapat dijadikan peluang untuk mempersiapkan kualitas masa dengan pembelajar.

Fenemona lain yang menyumbang urgensi pengembangan bahan ajar ialah untuk menghasilkan lulusan yang sesuai dengan standar kelulusan BIPA. Bahan ajar BIPA yang kurang, perlu mendapat sumbang sih dari peneliti. Oleh Ramliyani (2019:30) Program Bahasa Indonesia bagi Penutur Asing diibiratkan sebagai ladang subur yang tak bertuan, artinya siapa saja dapat menggarapnya dan memberikan perannya. Terlebih ihwal keterbatasan sumber belajar adalah hal yang krusial, mengingat sumber belajar tidak hanya terpaku pada satu buku teks atau buku acuan wajib. Terlebih, sebagaimana pernyataan Rahmawati (2018:5) diperlukan bahan ajar BIPA yang digunakan sebagai media dan sumber belajar pembelajar BIPA hendaknya mempertimbangkan aspek kesantunan berbahasa dalam penyajiannya Penelitian ini dirasa sangat penting mengingat terbatasnya bahan ajar untuk pemelajar BIPA yang memperhatikan nilai kesantunan dalam berbahasa Indonesia.

Arah penelitian ini adalah untuk mendeskripsikan pengembangan bahan ajar modul interaktif untuk pemelajar BIPA level A1. Secara umum penelitian ini akan bermanfaat bagi dunia pendidikan yang ada di Indonesia. Temuan ini diharapkan dapat bermanfaat bagi bidang kajian bahasa Indonesia, khususnya duniapengajaran BIPA. Penulis berharap dengan dilakukannya pengembangan bahan ajar ini akan menyempurnakan perangkat pembelajaran BIPA yang sebelumnya sudah ada.

Manfaat secara praktis yakni hasil penelitian ini dapat memberikan variasi bahan ajar yang dapat dimanfaatkan secara langsung oleh pembelajar BIPA. Pemanfaatan tersebut tentunya dengan catatan bahan ajar yang dikembangkan telah melalui tahap revisi dan mememenuhi standar kelayakan. Bagi pemelajar BIPA penelitian ini berguna 


Kredo 3 (2020)
KREDO: Jurnal Ilmiah Bahasa dan Sastra
Terakreditasi Sinta 4 berdasarkan Keputusan Direktorat
Jenderal Penguatan Riset dan Pengembangan,
Kementerian Riset, Teknologi dan Pendidikan Tinggi
Republik Indonesia
Nomor: 23/E/KPT/2019. 08 Agustus 2019
https://jurnal.umk.ac.id/index.php/kredo/index

karena memperkaya keterampilan berbahasa Indonesia. Semoga penelitian ini dapat bermanfaat dan dimanfaatkan dengan baik oleh pembaca yang budiman.

\section{KAJIAN TEORI}

\section{Hakikat Bahan Ajar}

Majid (2007:174) mendeskripsikan bahwa bahan ajar ialah segala bentuk bahan yang dapat difungsikan untuk membantu guru atau instruktur dalam melaksanakan kegiatan belajar mengajar. Depdiknas (2008:4) menjabarkan bahwa bahan ajar atau materi pembelajaran (instructional materials) sebagai pengetahuan, keterampilan, dansikap yang harus dipelajari pembelajar dalam rangka mencapai standar kompetensi yang telah ditentukan.

Menurut Prastowo (2018:51) bahan ajar adalah segala bahan (baik itu informasi, alat, maupun teks) yang disusun secara sistematis yang menampilkan sosok utuh dari kompetensi yang akan dikuasai peserta didik dan digunakan dalam proses pembelajaran dengan tujuan untuk perencanaan dan penelaahan implementasi pembelajaran.

Samuel (2009:61) berpendapat jika bahan ajar merujuk pada beberapa alternatif dalam proses komunikasi. Bahan ajar dapat digunakan oleh guru kelas untuk mengkonkretkan konsep pembelajaran selama proses belajar mengajar. Hadirnya bahan ajar juga dimaksudkan untuk menghindari aktivitas ceramah, sekaligus memberikan varasi cara penyampaian pesan atau materi dari guru ke siswa.

Widodo (2008:40) menyebut bahwa bahan ajar merupakan seperangkat sarana atau alat pembelajaran yang sejatinya berisikan materi pembelajaran, metode, batasan, dan cara mengevaluasai yang di desain secara sistematis dan menarik dalam rangka mencapai tujuan yang diharapkan untuk mencapai kompetensi atau subkompetensi dengan segala kompleksitasnya. Secara konkret Butcher (2006:130) menjelaskan bahwa alat bantu visual seperti selebaran dan slide/ overhead, yang meliputi teks, diagram dan gambar, plus media lain seperti audio, video dan animasi juga termasuk bahan dan sumber belajar.

\section{Hakikat BIPA}

Siroj (2015:79) menjelaskan bahwa pembelajaran BIPA adalah sebuah proses pemolaan berkaitan dengan perilaku belajar. Perilaku yang dimaksud adalah sikap yang berorientasi pada pembangkitan dan pengkondisian motivasi penutur asing dalam berbahasa Indonesia. Bahasa Indonesia untuk penutur asing (BIPA) merupakan suatu program pembelajaran bahasa yang dirancang secara khusus guna memberikan pelajaran bagi siswa asing yang hendak mempelajari bahasa Indonesia.

Purwiyanti menyebutkan bahwa pembelajaran bahasa Indonesia penutur asing (BIPA) sejatinya berfokus pada pemelajar asing yang bahasa pertamanya (B1) bukan bahasa Indonesia. Pemelajar asing adalah orang asing yang sengaja mempelajari bahasa Indonesia. Tidak hanya pada aspek pembelajaran bahasa Indonesia saja, tetapi pengenalan budaya Indonesia pun menjadi fokus pembelajaran BIPA. Yahya (2018:2) berargumen bahwa BIPA merupakan sebuah program pembelajarn bahasa Indonesia yang secara khusus ditujukan untuk warga negara asing (WNA), yang 


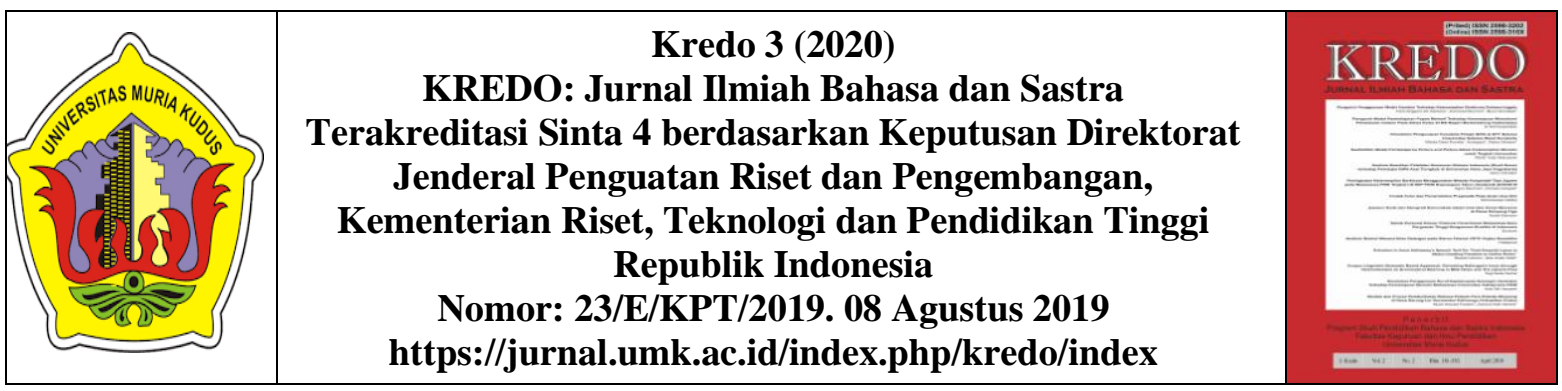

sekaligus berkedudukan sebagai subjek pembelajaran.

Ningrum (2017:727) menyatakan program BIPA adalah pembelajaran bahasa Indonesia yang subjeknya merupakan pembelajar asing. Maka bahasa Indonesia merupakan suatu bahasa asing bagi pemelajar BIPA. Lebih lanjut, Suyitno (2017:175) menyampaikan bahwa BIPA (bahasa Indonesia untuk penutur asing) dapat dimaknai sebagai program pembelajaran bahasa yang secara khusus dirancang guna memberikan pembelajaran bagi siswa asing yang berkeinginan untuk belajar bahasa Indonesia. Bahan dan proses belajar disesuaikan dengan kebutuhan dan tujuan siswa asing, memungkinkan siswa asing untuk berbicara dengan bahasa Indonesiadan menjadi terbiasa dengan kebudayaan yang ada di Indonesia.

\section{Karakteristik Modul Interaktif}

Secara umum Raharjo (2018:120) memaparkan bahwa bahan ajar multimedia interaktif ialah bahan ajar yang memanfaatkan penggunaan peangkat lunak yang telah dirancang sedemikian rupa agar dijalankan oleh siswa melalui computer. Daryanto (2013:9) memaparkan batasan modul sebagai salah satu wujud bahan ajar yang sengaja dikemas dan dirancang dengan format atau sistematika yang lengkap untuk memuat pengalaman belajar tertentu. Suatu modul dapat dikatakan interaktif apabila, mengakomodasi si pegguna untuk mengalami interaksi tertentu, mengalami hal tertentu seperti melihat gambar atau ilustrasi, warna, suara dan sebagainya (Abdullah, Herpratiwi, Tarkono, 2013:2).

Suwatra (2018:543) memaparkan bahwa teknologi informasi dan komunikasi (TIK) sebagai sumber belajar sebuah proses pembelajaran yang inovatif. Proses pembelajaran menjadi lebih bervariasi, tidak dibatasi oleh ruang, waktu, dan usia. Salah satu bentuk nyata dari pemanfaatan teknologi informasi dan komunikasi sebagai sumber belajar adalah lahirnya modul elektronik interaktif. Yayang (2019:27) dalam penelitiannya menyebut jika pengembangan dan penayangan modul dilakukan dengan memanfaatkan teknologi maka dapat dikatakan sebagai elektronik modul atau e-modul.

Imansari (2017:12) berpendapat bahwa e-modul merupakan modul dalam format elektronik yang dijalankan oleh komputer.Bahan ajar seperti materi, metode, batasan, aktivitas evaluasi yang didesain secara menarik sistemik untuk keteracapaian kompetensi tertentu adalah hakikat dari e-modul interaktif. Menurut Imansari, modul elektronik dapat menyajikan teks, gambar, animasi, dan video melalui komputer.

Pengembangan bahan ajar dalam wujud modul dapat disimpulkan sebagai serangkaian prosedur yang dilakukan untuk mengembangkan sistem pembelajaran modul. Tanjung (2018:80) menyarikan beberapa kriteria dalam pengembangan sebuah modul yakni (1) untuk membantu siswa dalam menyiapkan system pembelajaran mandiri, (2) memiliki rencana kegiatan belajar yang dapat ditanggapi secara maksimal, (3) menyajikan konten pembelajaran yang lengkap dan mampu memberikan kesempatan yang belajar yang sama kepada setiap siswa, (4) dapat memonitor aktivitas belajar siswa, dan (5) dapat memberikan saran, instruksi dan informasi untuk meningkatkan pembelajaran pada siswa. 


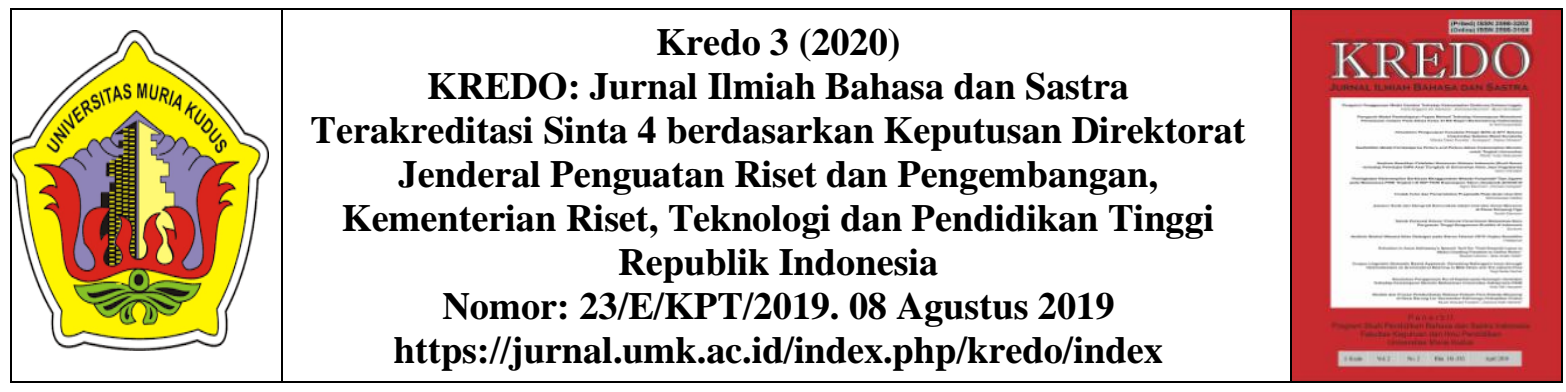

Peneliti mengklasifikasikan dua ragam pustaka yang relevan dengan riset ini, yakni pengembangan bahan ajar dan pembelajaran BIPA. Penelitian yang berhubungan dengan pengembangan bahan ajar telah dilakukan oleh Siroj (2015:74), Fariqoh (2016:219), Ramadhani (2016:326), Arumdyahsari (2016:828), Lubna (2017:83), dan Yayang (2019:25).Umumnya tujuan penelitian diatas adalah untuk mengembangkan model bahan ajar bahasa Indonesia bagi penutur asing baik pemelajar dewasa atau kanak-kanak dengan menyisipkan ranah budaya. Penelitian relevan yang mengangkat kajian BIPA sebelumnya telah dilakukan oleh beberapa peneliti diantaranya Suyitno (2017:52), Maharani (2018:121), Rahmawati (2018:125), Hermoyo (2017:120), dan Wiratsih (2019:242).

\section{METODE PENELITIAN}

Penelitian di desain menggunakan jenis penelitian pengembangan Research and Development (R\&D). Dengan kata lain, penelitian pengembangan adalah sebuah proses yang menghasilkan sebuah produk. Penulis memilih metode penelitian tersebut karena tujuan akhir penelitian ini adalah untuk mengembangkan produk bahan ajar keterampilan berbahasa reseptif berbasis e-modul bagi pemelajar BIPA. Sugiyono (2010:298) menyatakan penelitian pengembangan menggunakan prosedur dan langkah sebagai berikut: (1) potensi dan masalah, (2) pengumpulan data, (3) desain produk, (4) validasi desain, (5) revisi desain, (6) uji coba produk, (7) revisi produk, (8) uji coba pemakaian, (9) revisi produk, dan (10) produk masal.
Tidak semua tahapan dilakukan oleh penulis hal tersebut mengingat ada beberapa tahap yang mengulang dari tahap sebelumnya. Penelitian ini dirancang dengan tahap penggalian potensi dan masalah, mengumpulkan data terkait, membuat rancangan bahan ajar, pengembangan bahan ajar, dan revisi desain. Penulis memilih metode penelitian tersebut karena tujuan akhir penelitian ini adalah untuk mengembangkan bahan ajar berbasis modul interaktif bagi pemelajar BIPA tingkat A1 berdasarkan pada analisis kebutuhan.

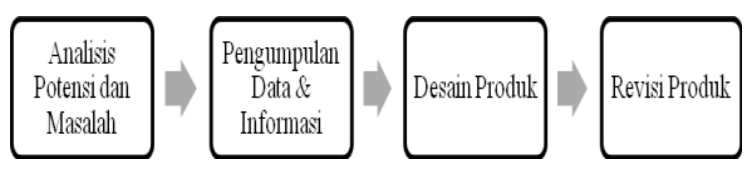

Gambar 1 Langkah kerja penelitian diadaptasi dari Sugiyono

\section{HASIL DAN PEMBAHASAN}

\section{Analisis Potensi dan masalah}

Survei dilakukan sebagai langkah awal dari penelitian ini. Penggalian potensi dan permasalahan diawali dengan melakukan penjajakan penelitian relevan. Tidak hanya berpaku pada kajian pustaka, penulis melakukan observasi yang dilakukan untuk menggali potensi dan masalah yang hendak dikaji. Observasi dilakukan di kelas BIPA Universitas Muhammadiyah Surakarta. Selanjutnya, analisis potensi pengembangan bahan ajar juga didapat dari aktivitas wawancara dengan pengajar BIPA di Universitas Muhammadiyah Surakarta.

Analisis kebutuhan adalah langkah awal untuk melakukan sebuah pengembangan guna mengetahui 


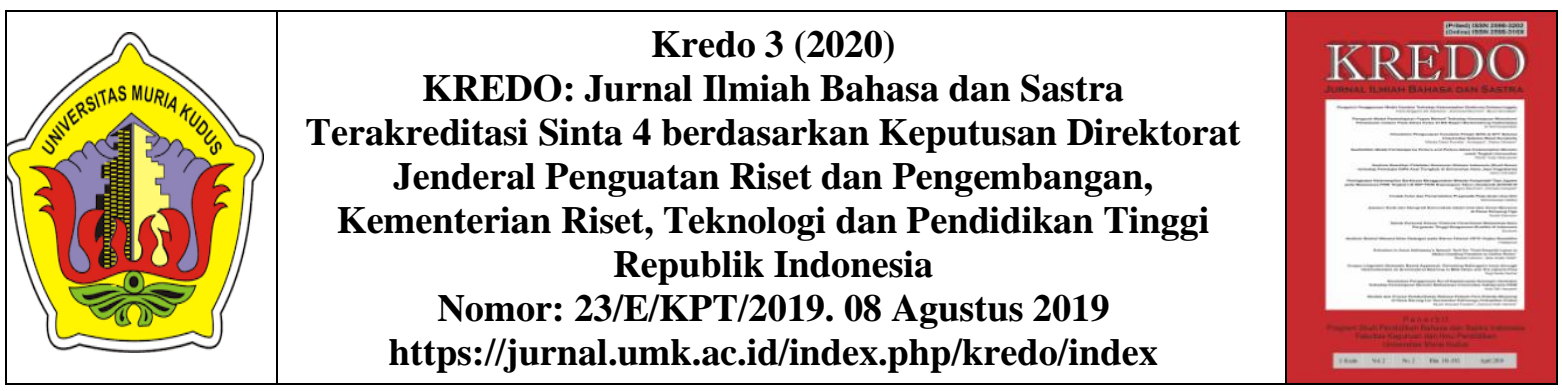

kebutuhan pemelajar, pembelajar, sekaligus institusi dalam mempelajari bahasa terget (Prasetiyo, 2017:232). Pada kajian ini, peneliti melakukan penjaringan data analisis kebutuhan terhadap bahan ajar yang hendak dikembangkan melalui aktivitas wawancara. Wawancara tersebut melibatkan pembelajar BIPA yang aktif mengajar di Universitas Muhammadiyah Surakarta. Adapun narasumber tersebut adalah Dr. Laili Etika Rahmawati.

Analisis kebutuhan dapat dimaknai pula sebagai tahapan awal penggalian potensi sekaligus masalah yang ada. Pembelajar BIPA adalah praktisi yang secara langsung mampu mengidentifikasi apa yang dibutuhkan oleh si pemelajar. Simpulan dari analisis kebutuhan tersebut akan berwujud karakteristik pengembangan bahan ajar sesuai persepsi pembelajar BIPA.

Melalui aktivitas wawancara, peneliti mendapatkan infomasi bahwa pembelajaran BIPA di Unversitas Muhammadiyah Surakarta selama ini hanya mengandalkan buku Sahabatku Indonesia jenjang AI yang diterbitkan oleh Pusat Pengembangan Strategi dan Diplomasi Kebahasaan Badan Pengembangan dan Pembinaan Bahasa Kementerian Pendidikan dan Kebudayaan. Buku tersebut adalah buku ajar bahasa Indonesia bagi penutur asing yang telah diterbitkan di tahun 2016 dan masih dimanfaatkan sampai sekarang.

\section{Pengumpulan Data dan Informasi}

Pada sesi ini peneliti berusahan untuk melakukan penjaringan data standar kelulusan BIPA level A. Selanjutnya, penulis berusaha untuk mengumpulkan informasi pendukung terkait kajian atau teori keterampilan berbahasa yang bersumber dari buku, jurnal, ataupun prosiding. Mengkaji materi berbahasa yang hendak diintegrasikan dalam modul yang hendak dikembangkan, dalam proses ini pemilihan materi harus mengacu pada standar ketercapaian lulusan BIPA, dan level BIPA itu sendiri. Teknik simak dan catat digunakan dalam rangka mengumpulkan data terkait materi berbahasa dalam modul, bentuk soal, bahan bacaan terbarukan, dan analisis modul yang sudah ada yang telah digunakan oleh pemelajar BIPA sebelumnya.

\section{Desain produk}

Produk didesain dengan awalan menentukan tujuan pembelajaran atau capaian pembelajaran modul. Modul kali ini dirancang dengan tujuan agar pemelajar mampu memahami dan menggunakan ungkapan konteks perkenalan diri dan pemenuhan kebutuhan konkret sehari-hari dan rutin dengan cara sederhana untuk berkomunikasi dengan mitra tutur yang sangat kooperatif. Produk didesain dengan alur berikut:

1) merancang tujuan pembelajaran atau capaian pembelajaran melalui modul,

2) pemilihan materi atau konten,

3) pengumpulan ilustrasi pendukung,

4) penyesuaian materi atau konten dengan ilustrasi, dan

5) finalisasi desain sesuai spesifikasi yang telah ditentukan.

Produk yang dikembangan berupa bahan ajar berupa modul interaktif dengan spesifikasi sebagai berikut:

1. Modul yang diproduksi ditujukan kepada pemelajar program BIPA level pemula 


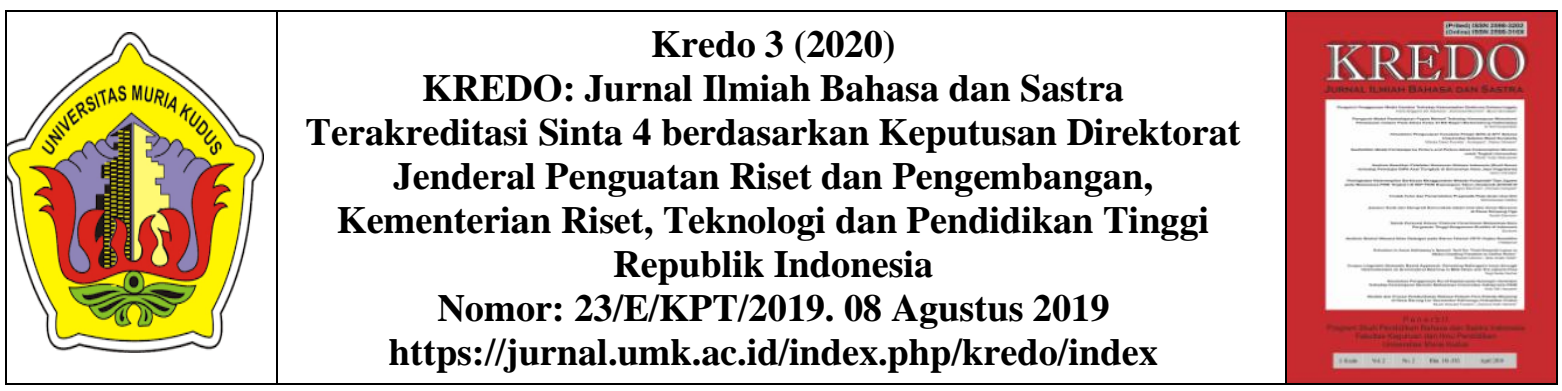

2. Modul yang dibuat berupa modul elektronik (e-modul) hanya dapat diakses dengan perangkat elektronik

3. Modul dibuat dengan menyuguhkan perpaduan empat keterampilan berbahasa yakni mendengarkan, membaca, menulis, dan berbicara

4. Modul didesain dengan pendekatan kontekstual dan interaktif

5. Modul ini dikembangkan berdasarkan standar kompetensi lulusan program BIPA tingkat pemula (A1).

6. Modul ini berfokus pada standar kelulusan mengaktualisasi karakter dan kepribadian peserta didik BIPA. Berikut elemen 1.5 yaitu menghargai keanekaragaman budaya, pandangan, kepercayaan, dan agama sertapendapat / temuan original dari orang lain. Indikator yang menjadi perhatian adalah menunjukkan sikap menghargai keanekaragaman budaya, pandangan, kepercayaan, dan agama serta pendapat / temuan original dari orang lain. Standar kelulusan tersebut dipilih mengingat bangsa Indonesia adalah bangsa yang plural kebudayaan, agama, kearifan lokal dan sebagainya, menurut peneliti pemahaman akan bangsa Indonesia yang memiliki keanekaragaman tersebut perlu yang sebaiknya dikenalkan dan dieksplorasi terlebih dahulu. Modul tersebut juga memuat kemampuan di bidang kerja, seperti mampu memahami dan menggunakan konteks perkenalan diri dan pemenuhan kebutuhan konkret secara sederhana. Bahan ajar berikut juga menyuguhkan materi pengenalan sekaligus penggunaan kata ganti orang dengan wujud kalimat sederhana.

284 | Jurnal Kredo

Vol. 3 No. 2 April 2020
Modul ini memuat konten kata pengantar, petunjuk penggunaan, informasi unit keterampilan, tujuan belajar, materi singkat, latihan soal, dan glosarium.

7. Modul ini dilengkapai ilustrasi multimedia autentik pendukung aktivitas belajar.

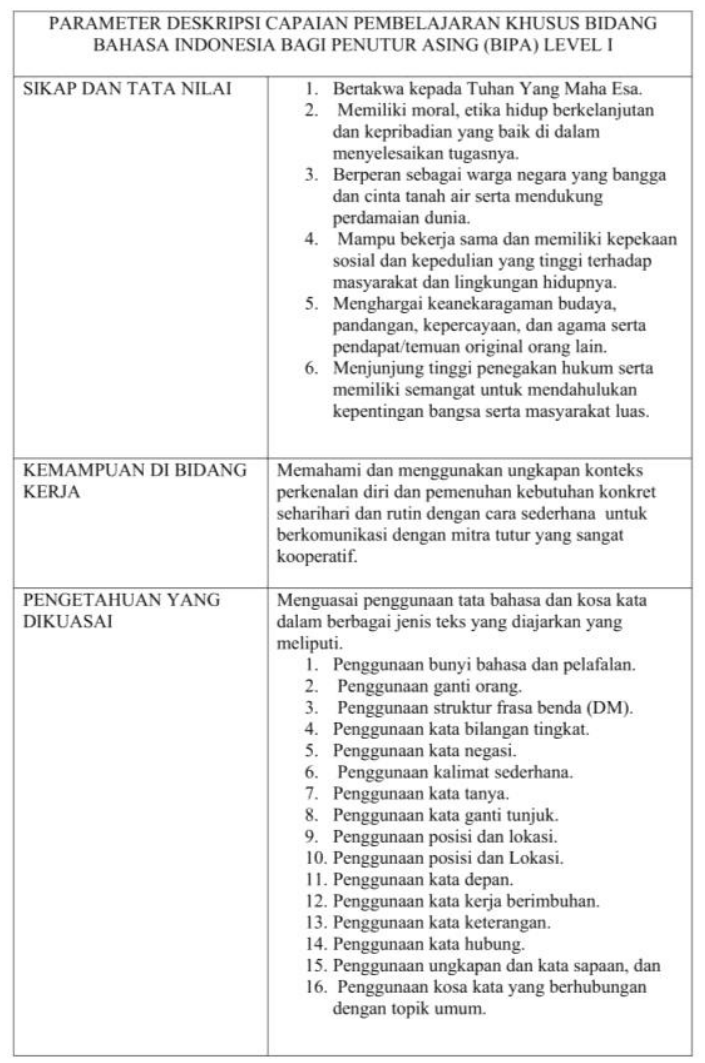

Gambar 2 Parameter Capaian BIPA level 1

Berikut adalah peta konsep pengembangan konten dalam modul yang telah diturunkan dari capaian pembelajaran BIPA level 1 (poin 5) sebagaimana yang tertuang dalam Permendikbud Nomor 27 Tahun 2017: 

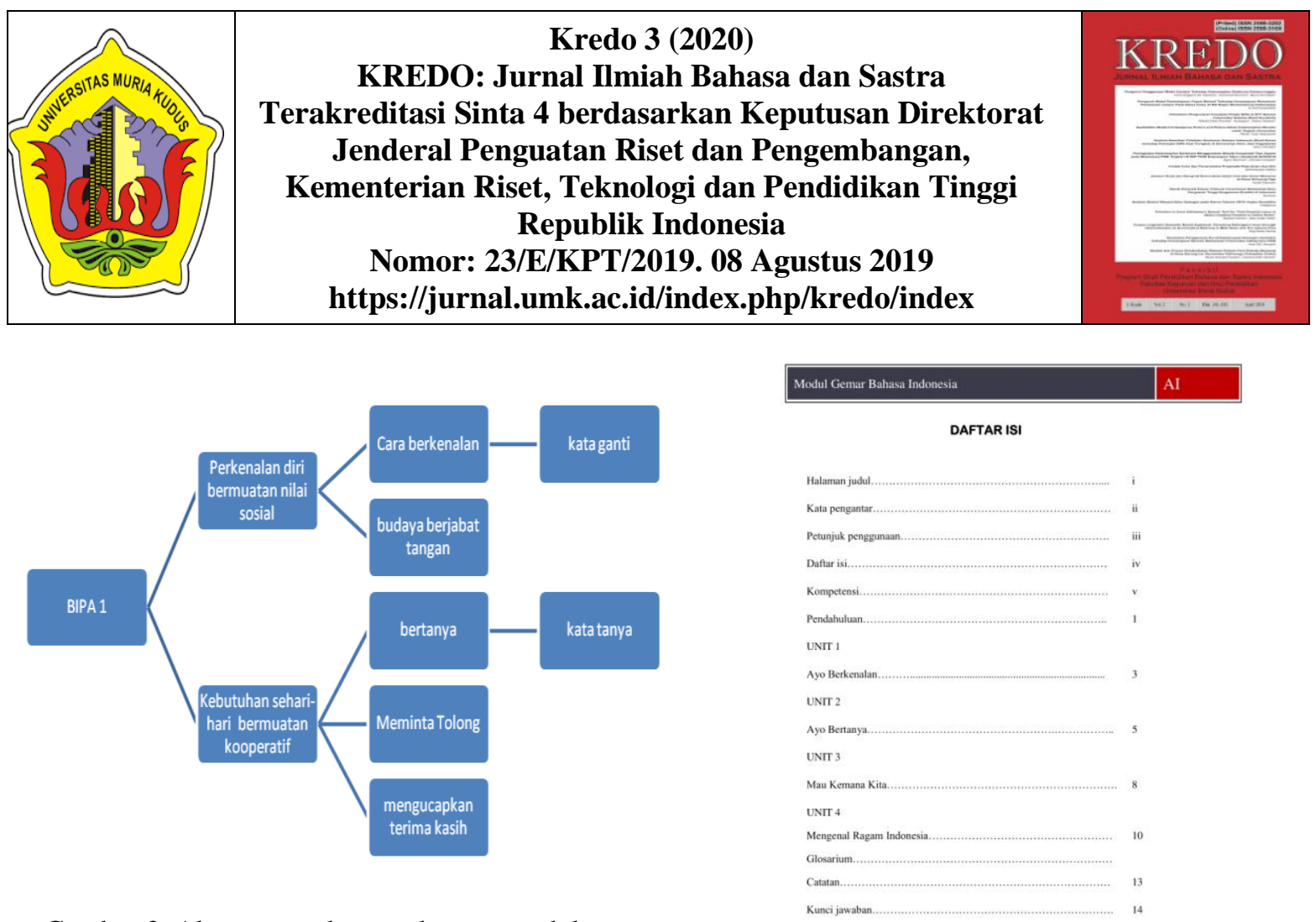

Gambar 3 Alur pengembangan konten modul

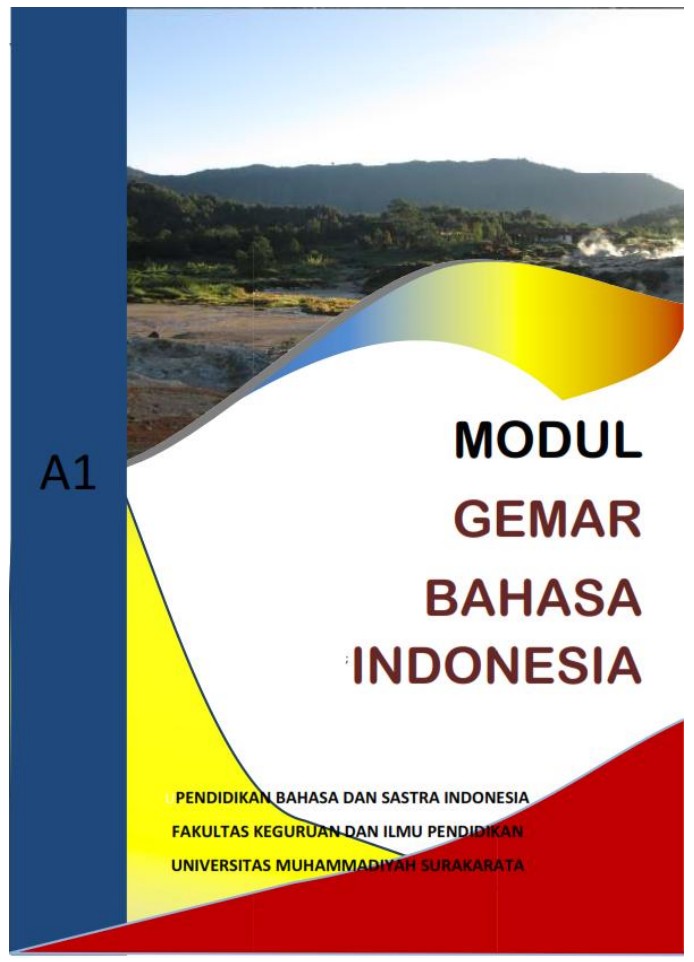

Gambar 4 Sampul modul

\section{Gambar 5 Daftar isi modul}

Penelitian pengembangan ini menghasilkan bahan ajar berupa modul elektronik interaktif yang bertajuk Gemar Bahasa Indonesia Level A1 (pemula). Produk ini dirancang untuk memenuhi kebutuhan bahan ajar bagi pemelajar BIPA berdasarkan persepsi pembelajar. Produk Hal tersebut mengingat, lembar kerja atau modul harus sesuai dengan tujuan program dan hasilnya sesuai dengan kebutuhan individu (Hoffmann, 2013:120).

Keputusan untuk menghasilkan modul elektronik adalah upaya untuk mencari cara baru yang melibatkan peserta didik dan memberi mereka pengalaman belajar yang lebih interaktif. Hal tersebut sejalan dengan tren dan inisiatif global untuk sepenuhnya melakukan kegiatan migrasi konten pembelajaran ke $\mathrm{E}$ atau eloktronik (Zabidi dkk, 2017:76). E-modul disediakan pada sistem manajemen pembelajaran untuk pelajar yang ingin 


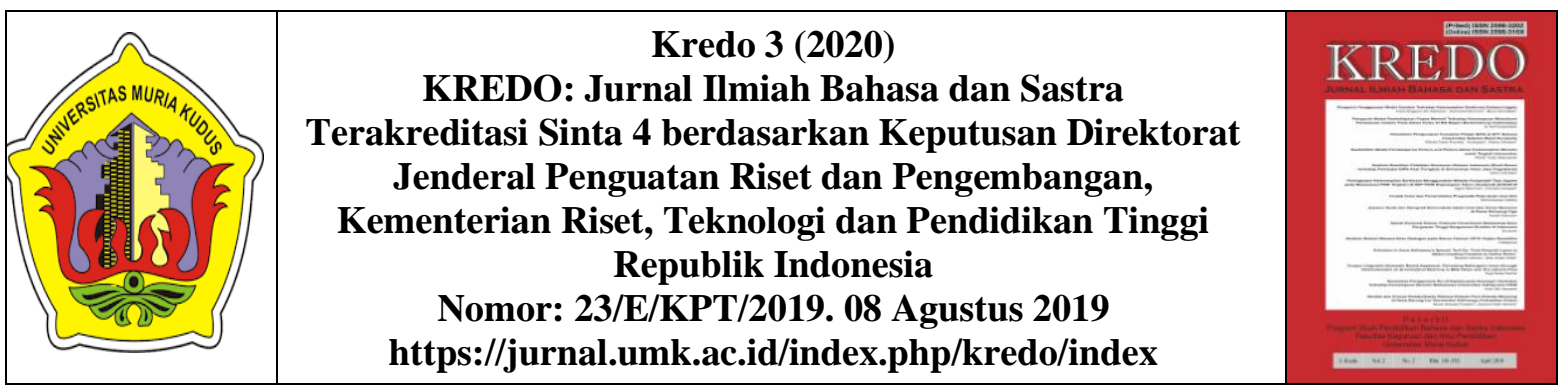

mengunduhnya dalam format PDF. Peserta didik dapat mengunduh seluruh modul atau mengunduh masing-masing topik secara terpisah. Penulis mengacu batasan interaktif adalah siswa mampu merespon dan menanggapi stimulus yang berasal dari tampilan komputer (Ilyas \& Mursid, 2015:144). Dari batasan tersebut, perlu diperjelas bahwa modul ini dirancang hanya sebagai tampilan komputer, tidak dicetak, atau dikenal juga dengan sebutan modul elektronik.

Inisiatif pengembangan dapat dianggap sebagai respon terhadap pertimbangan biaya dan logistik produksi modul konvensional yang tidak murah. Modul elektronik dapat menawarkan pengalaman belajar berkualitas, berkelanjutan karena dapat digunakan dalam jangka panjang, dan minim resiko kerusakan produk. Lahirnya modul ini, dapat dianggap sebagai sebuah alternatif yang akan memudahkan pembelajar dalam memfasilitasi siswa yang memiliki karakteristik dan kecepatan belajar yang berbeda-beda (Purwaningtyas, 2017:122). Melalui temuannya Prasetiyo (2017:229) mengungkapkan bahwa dalam beberapa tahun terakhir, kita tidak dapat menutup mata terhadap munculnya suatu multimedia interaktif yang kini mendominasi bidang pengajaran bahasa. Akan tetapi ide modul interaktif adalah hal yang baru dalam bidang pengajaran bahasa Indonesia bagi penutur asing (BIPA).

Penulis mempertimbangkan kenyataan dunia pendidikan, bahwa ada beberapa pemelajar yang tidak mendapat pengetahuan dengan maksimal dalam proses pembelajaran secara konvensional. Selain itu, modul elektronik adalah wujud jaringan pembelajaran pribadi berkembang dari gagasan untuk membangun lingkungan pembelajaran yang mandiri, yang dibangun dari kumpulan alat web yang diatur dan dimiliki oleh pelajar. Dengan cara ini, manajemen pembelajaran bermigrasi dari institusi ke pelajar 'dan belajar juga' berkembang dari menjadi transfer konten dan pengetahuan untuk produksi konten dan pengetahuan (Downes, 2007:19).

Modul Gemar Bahasa Indonesia A1 terdiri dari bagian sampul modul, kata pengantar, petunjuk penggunaan produk, daftar isi, deskripsi kompetensi yang hendak dicapai, pendahuluan, unit 1 , unit 2 , unit 3, unit 4, glosarium, catatan, dan kunci jawaban. Modul yang dirancang memiliki spesifikasi sebagai berikut; ukuran kertas A4, jenis huruf Times New Roman, dan jumlah halaman 25.

Bahan ajar ini dilengkapi berbagai ilustrasi autentik yang telah dipilih oleh penulis untuk membantu menggiring pemahaman si pemelajar. Hal tersebut berbeda dengan penyusunan bahan ajar untuk anak yang berwarna dan penuh gambar menarik untuk menggugah minat belajar bahasa (Lubna, 2017:93). Suyitno dkk (2017:56) menyebut materi autentik sengaja dipilih untuk mengatasi isu bentrokan situasi kebudayaan dan dapat mengaktualisasikan diri secara tepat dalam berbahasa Indonesia. Umam (2015:2) mendeskripsikan 16 prinsip pengembangan bahan ajar untuk pengajaran bahasa atau linguistik dengan salah satu prinsip berbunyi materi pembelajaran harus memaparkan kegunaan bahasa secara autentik. Berikut adalah salah satu contoh materi autentik dalam modul. 


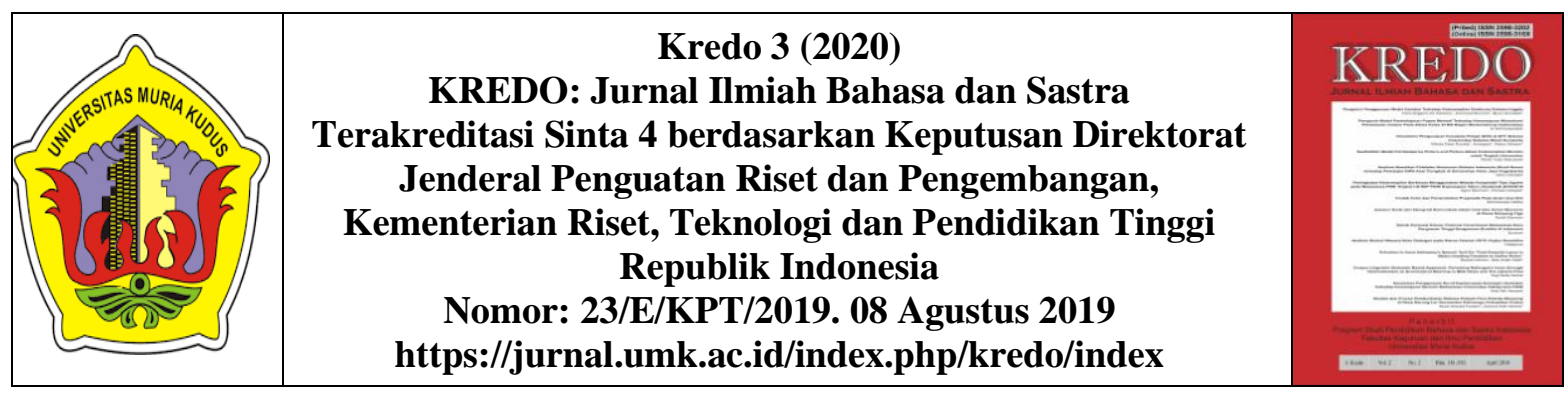

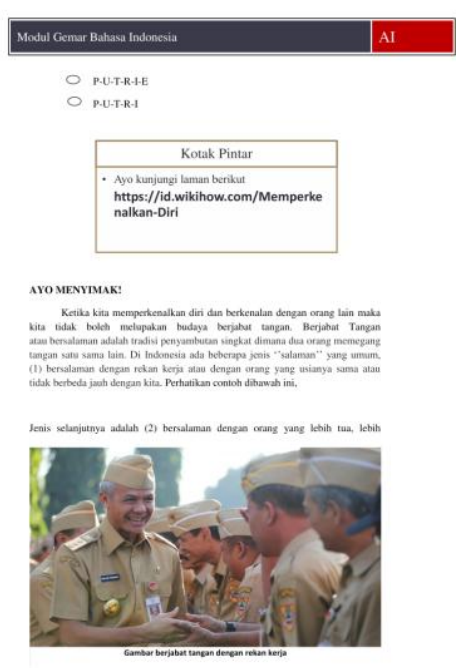

Gambar 6 Contoh materi autentik

Bahan ajar ini menggunakan pendekatan interaktif dan berfokus pada keterampilan dasar berbahasa Indonesia untuk BIPA level pemula. Holmberg menegaskan bahwa konten yang terkandung dalam modul harus interaktif artinya "suatu elemen dari diskusi didaktik yang dipandu, yang dapat meningkatkan ketrampilan, kedekatan dan komunikasi dua arah antara pelajar dan materi atau antara pelajar dan penulis modul" (Zabidi, 2017:75). Modul gemar berbahasa Indonesia Level A1 diciptakan dengan misi menyediakan bahan ajar yang sesuai dengan kategori pemelajar dewasa. Pemilihan konten dalam modul tentunya lebih diperhatikan dan disesuaikan dengan kebutuhan orang dewasa. Kebutuhan orang dewasa dan memfasilitasi kegiatan akademik yang dimaksud adalah (1) cara memperkenalkan diri, (2) pengetahuan umum dan (3) pengenalan budaya Indonesia.

Materi cara memperkenalkan diri disampaikan dengan bagaimana cara penyampaian dan pelafalan nama, serta pengenalan budaya bersalaman yang identik ketika seseorang tengah memperkenalkan diri. Modul ini juga menyajikan cara bagaimana pemelajar dapat melafalkan namanya mengingat pelafalan adalah salah satu bagian yang penting dalam pembelajaran bahasa (Budiawan \& Rukayati, 2018:92). Aktivitas pelafalan dimulai dengan mencoba menuliskan nama pemelajar sendiri, kemudian dilanjutkan dengan menuliskan nama teman terdekat. Kemudian, pemelajar diarahkan untuk mampu melafalkan bunyi nama mereka dengan benar. Materi memperkenalkan diri sengaja dikemas sedemikian rupa, seperti contoh dibawah menyajikan kartu nama sehingga terwujud keterampilan komunikasi secara praktis. Kartu nama sengaja dipilih, karena memuat pengenalan dan penggunaan kosakata yang berhubungan dengan topik umum, seperti nama, pekerjaan, alamat, dan sebagainya.

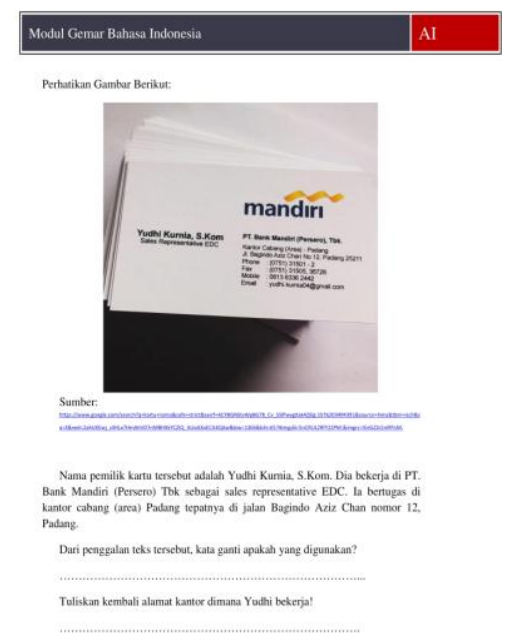

Gambar 7 konten memperkenalkan diri dalam modul 


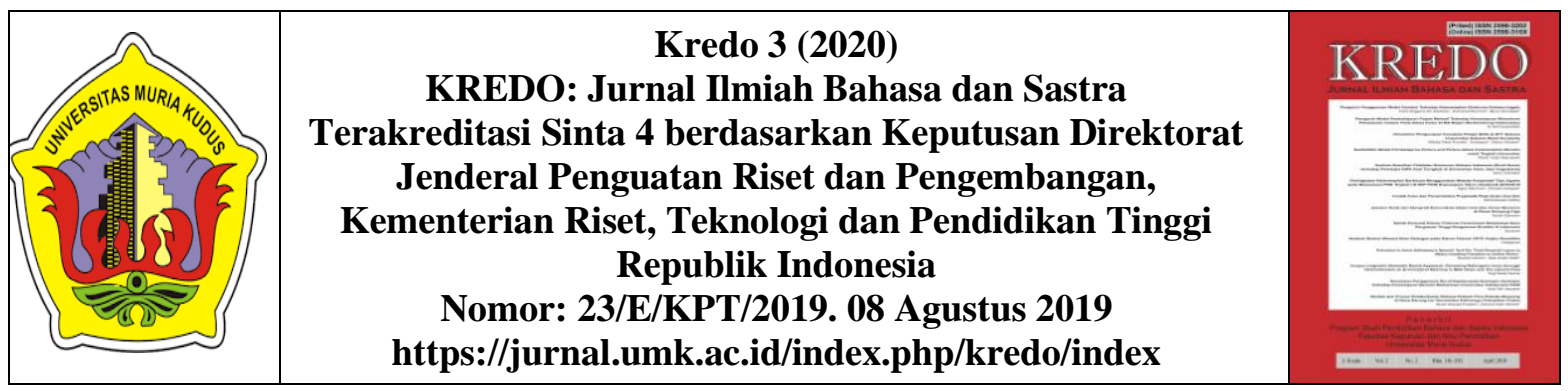

Akan lebih bijak apabila dalam sebuah bahan ajar disajikan contoh yang mendukung. Contohnya, dalam unit menyapa, penulis bisa saja memasukkan contoh kasus bagaimana cara dan di situasi seperti apa orang Indonesia menyapa lawan tutur. Informasi tersebut dapat digunakan sebagai pemberian contoh yang bertujuan untuk mempraktikkan contoh sekaligus. Hal tersebut berkaitan erat dengan kompetensi komunikatif dan sosiolinguistik. Rahmawati (2018:126) menuturkan bahwa kompetensi komunikatif merupakan kompetensi dalam memahami dan menggunakan bahasa dalam kegiatan komunikasi secara faktual dan masuk akal sesuai dengan konteks percakapan yang ada. Kompetensi sosiolinguistik ialah kompetensi yang bertalian dengan kemampuan seseorang dalam menggunakan bahasa agar sesuai dengan kondisi sosial masyarakat.

Unit latihan atau evaluasi adalah unit yang tak kalah penting dari unit lainnya. Pada unit ini, akan diukur ketercapaian tujuan belajar pemelajar BIPA. Bahan ajar yang kita jumpai, sering menggunakan metode esai, pilihan ganda, menjodohkan sebagai tolok ukur belajar, sangat membosankan bukan? Bahan ajar yang dibutuhkan bukan hanya hanya untuk mengakomodasi aktivitas belajar, tetapi juga harus dirancang sekreatif mungkin untuk menularkan motivasi dan minat untuk belajar.

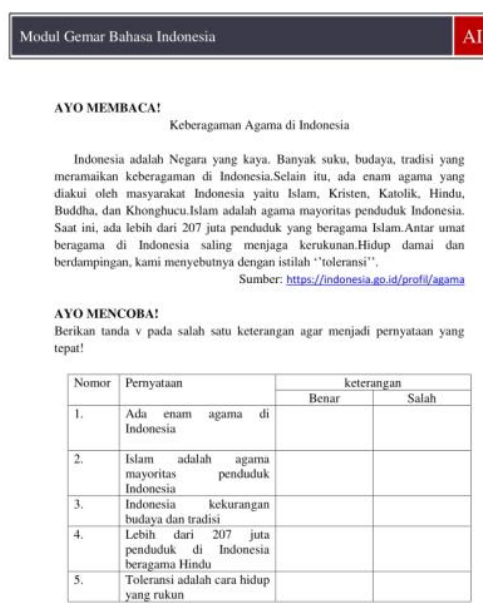

Gambar 8 contoh evaluasi dalam modul

Lebih lanjut, sesi evaluasi dalam bahan ajar harus mampu mengukur hasil belajar pemelajar BIPA. Bagaimana caranya menjadikan sesi ini lebih efektif dan bermakna bagi perkembangan pembelajaran bahasa mereka? Kita harus mencermati bentuk tes yang akan disajikan, baik tes keterampilan membaca, menyimak, berbicara, dan menyimak. Tes empat kompetensi berbahasa sekali lagi seyogyanya disesuaikan dengan karakteristik pemelajar dewasa. Mulai dari menentukan jenis tes yang akan diaplikasikan, merumuskan tujuan tes, dan diakhiri dengan merinci hasil yang harus diukur. Pertanyaan yang ditujukan ke pemelajar BIPA tidak asal pertanyaan, harus melalui bebarapa tahapan seperti penjelasan diatas.

Kata ganti adalah materi tata bahasa yang disisipkan dalam sesi perkenalan. Materi tata nilai yang berkaitan dengan kehidupan sehari-hari seperti bagaimana cara bertanya, meminta tolong, dan 


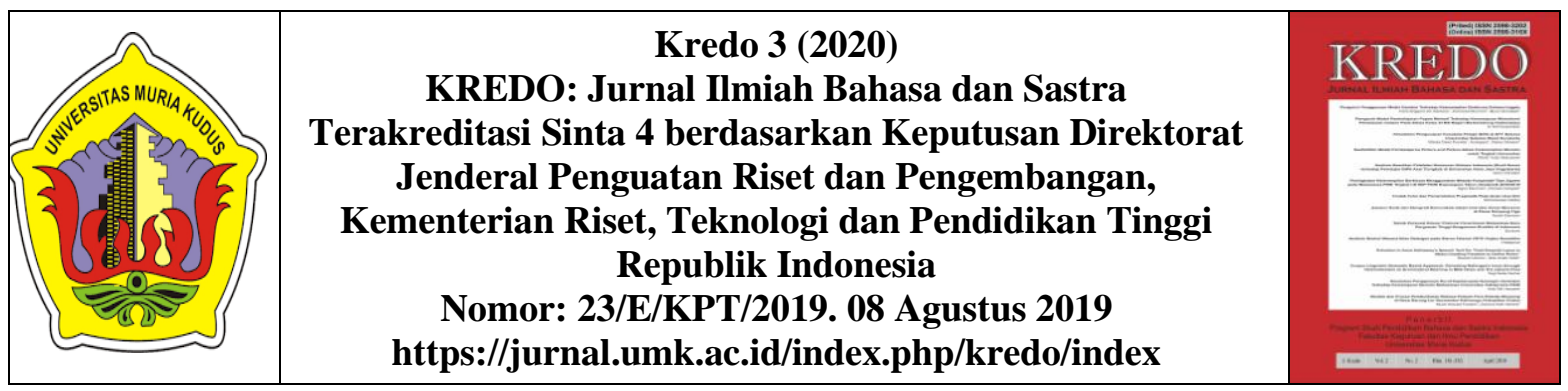

menyampaikan ucapan terima kasih, disampaikan dengan pemilihan kata yang santun. Penyajian beberapa materi tersebut juga dilengkapi dengan latar cerita yang sesuai. Hal tersebut sejurus dengan pernyataan Pandin (2019:512) pemelajar perlu diberikan informasi latar yang sesuai dengan tempat atau lingkungan kemasyarakatan yang tengah berlangsung. Modul 'Gemar Bahasa Indonesia A1" menampilkan latar belakang cerita secara faktual dan dimungkinkan mendekati keseharian pemelajar asing yang sedang belajar bahasa Indonesia di Indonesia secara langsung. Pengenalan lingkungan kampus Universitas Muhammadiyah Surakarta dan citra kota Solo melatari pengembangan modul ini. Pemilihan latar kampus dan kota Solo dilatarbelakangi oleh semangat agar pengetahuan dan informasi yang didapat dari modul dapat langsung diimplementasikan oleh pemelajar asing.

Ramadhani (2016:326) menyatakan bahwa pengajaran bahasa Indonesia bagi pembelajar BIPA perlu memperhatikan diksi atau pemilihan kata dan struktur benar dan harus sesuai dengan konteks. Hal ini dilakukan agar bahasa Indonesia yang diipelajari oleh pembelajar BIPA nantinya dapat berterima dan sesuai dengan logika berbahasa Indonesia. Percakapan yang ditampilkan dalam modul adalah fiktif belaka rekaan dari penulis. Penulis menyajikan nama, karakter, konteks yang telah dipertimbangkan dengan matang dan memenuhi citra keragaman budaya yang ada di Indonesia. Berikut adalah salah satu contoh pengenalan keragaman budaya Indonesia melalui tradisi kuliner.

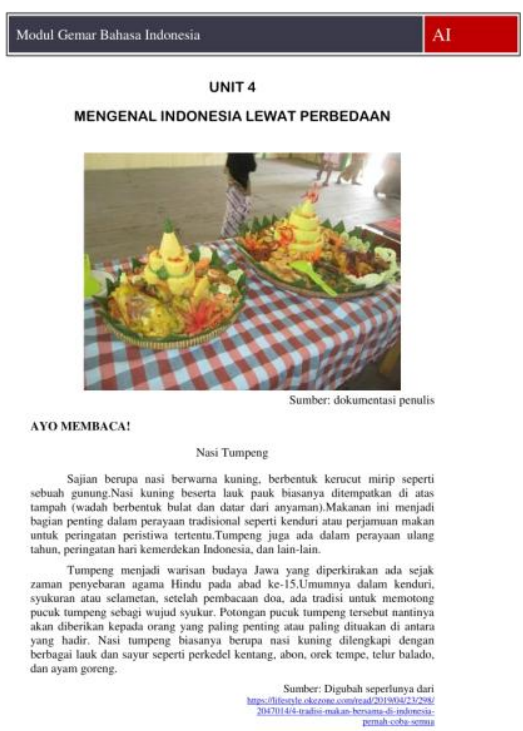

Gambar 9 Citra Keragaman budaya dalam modul

Penulis menggunakan silabus dan dokumen standar capaian kelulusan sebagai sumber acuan berpikir, pemilihan, dan pembuatan bahan ajar. Pengembahan bahan ajar telah dilakukan berdasarkan dokumen Peraturan Menteri Pendidikan dan Kebudayaan Nomor 27 Tahun 2017 tentang Standar Kompetensi Lulusan Kursus dan Pelatihan Bidang Keterampilan Kepemanduan Wisata, Pemeliharaan Taman, Pekarya Kesehatan, Petukangan Kayu Konstruksi, Pemasangan Bata, Perancah, Pemasangan Pipa, Mekanik Alat Berat, Bahasa Indonesia Bagi Penutur Asing, Pembuatan Batik Dengan Pewarna Ramah Lingkungan, Pembuatan Malam Batik, Pembuatan Batik Dengan Pewarna Sintetis, Pembuatan Alat Canting Tulis, Dan Pembuatan Canting Cap. Ketepatan materi yang disajikan dalam bahan ajar melalui pertimbangan dengan latar belakang sosial dan ekonomi siswa, usia dan perkembangan 


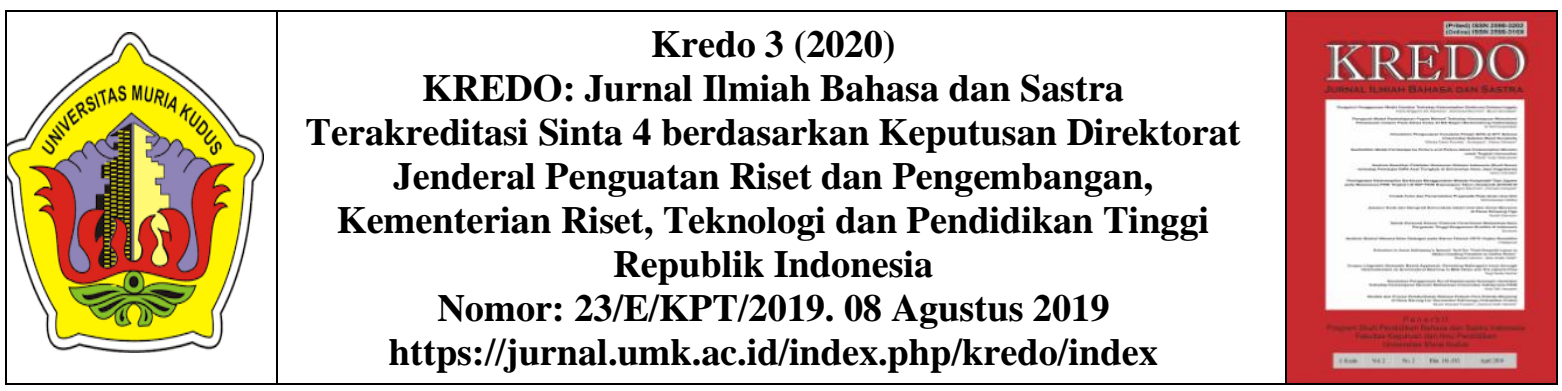

jiwa siswa, serta kebutuhan pemelajar BIPA itu sendiri.

Wujud wacana yang digunakan dalam modul adalah wacana sederhana, telah disesuaian dengan kemampuan berbahasa Indonesia si pemelajar. Bahan ajar akan menyajikan wacana dialog dikolaborasikan dengan metode membaca nyaring, yang akan melatih kemampuan membaca sekaligus berbicara. Pendapat tersebut senada dengan Irma (2018:157) menyebut bahwa harapan dan tuntutan mahasiswa asing adalah agar mampu merealisasikan keterampilan berbicara.

Temuan ini adalah sebuah proses awal untuk mewujudkan pengajaran BIPA yang lebih mutakhir. Dengan hadirnya rancangan modul untuk pemelajar BIPA A1, proses pembelajaran akan dapat lebih berjalan dengan maksimal. Bahan ajar yang dihasilkan dari penelitian ini, akan berterima di kalangan pemelajar BIPA karena dirancang sesuai dengan kebutuhan dari persepsi pembelejar dan layak bagi pemelajar BIPA dewasa. Kemudahan dan kemajuan teknologi yang ditawarkan oleh peradaban seyogyanya dimanfaatkan dengan baik. Tidak ada gading yang tak retak, tidak ada segala sesuatu yang seutuhnya sempurna di dunia ini. Begitupun, dengan riset ini yang tentunya memiliki celah dan keterbatasan, yakni analisis kebutuhan untuk pengembangan modul ini belum melibatkan jejak pendapat dari pemelajar BIPA dan hanya berdasarkan persepsi pembelajar. Selanjutnya, riset ini memiliki keterbatasan yaitu produk yang dikembangkan belum diujicobakan dan diteliti tingkat efektivitasnya.

\section{SIMPULAN}

Berdasarkan riset yang telah dilakukan, penulis menemukan bahwa: (1) pengembangan bahan ajar berbasis modul dibutuhkan oleh pembelajar mengingat buku ajar yang digunakan hanya satu, perlu tambahan lain untuk memperkaya sumber belajar dan ketidaksesuaian konten dalam buku ajar dengan karakteristik pemelajar dewasa (2) pengembangan produk berupa modul interaktif bagi pemelajar BIPA bertajuk "Gemar Berbahasa Indonesia A1" telah dilakukan dengan menyesuaikan kebutuhan dari persepsi pembelajar dan karakteristik pemelajar dewasa. Implikasi dari riset ini adalah modul yang dikembangan dapat dijadikan salah satu referensi bahan ajar pengajaran BIPA. Apabila modul ini hendak digunakan dalam praktik pembelajaran, maka diperlukan pengujian standar kelayakannya sebuah bahan ajar.

\section{DAFTAR PUSTAKA}

Arumdyahsari, S., Hs, W., \& Susanto, G. 2016. Pengembangan Bahan Ajar Keterampilan Berbicara Bahasa Indonesia Bagi Penutur Asing Tingkat Pemula. Jurnal Pendidikan Teori, Penelitian, dan Pengembangan, 1(5), 828-834.

Abdullah., Herpratiwi, \& Tarkono. 2013. Pengembangan Bahan Ajar Modul Interaktif Konsep Dasar Kerja Motor 4 Langkah. Jurnal Teknologi Informasi Komunikasi Pendidikan, $1(1)$, 1-13. 

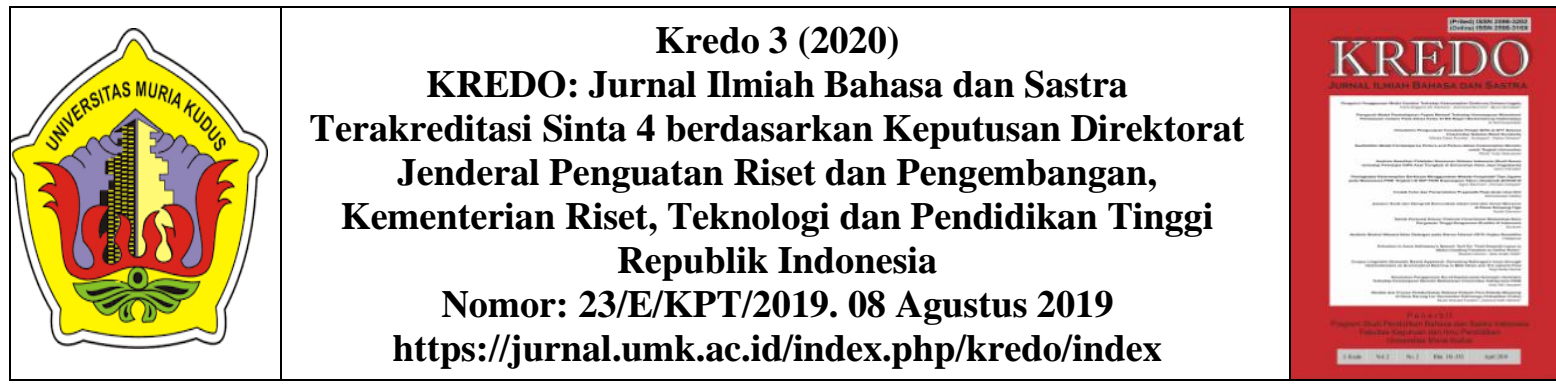

Arsanti, M. 2018. Pengembangan Bahan Ajar Mata Kuliah Penulisan Kreatif Bermuatan Nilai-nilai Pendidikan Karakter Religius Bagi Mahasiswa Prodi PBSI, FKIP, UNISSULA. Jurnal Kredo, 1(2), 71-90.

Butcher, C., Clara, D., \& Melissa, H. 2006. Designing Learning from Module Outline to Effective Teaching. New York: Routledge.

Budiawan, R., \& Rukayati. 2018. Kesalahan Bahasa dalam Praktik Berbicara Pemelajaran Bahasa Indonesia Bagi Penutur Asing (BIPA) di Universitas PGRI Semarang Tahun 2018. Jurnal Kredo, 2(1),-8897.

Celik, L. 2010. Evaluation of the Views of Pre-Service Teachers Taught with Moodle During the Course Named "Instructional Technology and Material Design" on the use of Teaching Materials. Procedia Social and Behavioral Sciences, 9, 1793-1797.

Depdiknas. $2008 . \quad$ Panduan Pengembangan Bahan Ajar. Jakarta: Depdiknas.

Downes, S. 2007 'Learning Networks in Practice' in Ley, DE (ed) Emerging Technologies for Learning volume 2 . London, BECTA. http://dera.ioe.ac.uk/1502/

Fariqoh, R. 2016. Pengembangan Bahan Ajar Membaca untuk
Pembelajar Bahasa Indonesia Penutur Asing Tingkat Dasar. Riksa Bahasa, 2(2), 219-223.

Hermoyo, R. P., \& Suher. 2017. Peranan Budaya Lokal dalam Materi Ajar Bahasa Indonesia Bagi Penutur Asing (BIPA). Jurnal Pendidikan dan Pembelajaran Sekolah Dasar, 1(2), 120-126.

Hoffmann, T. 2013. Reflecting on the Importance of Reflection and Critical Analysis in Prior Learning Portfolios: Instructional Materials Designed to Enhance and Guide the Portfolio Development and Evaluation Process. Journal of Continuing Higher Education, 61(2), 116-121.

Ilyas \& Mursid, R. 2015. Pengembangan Bahan Ajar Berbasis Multimedia Interaktif pada Pembelajaran Keterampilan Komputer dan Pengelolaan Informasi. Jurnal Teknologi Informasi \& Komunikasi dalam Pendidikan, 2(2), 142155.

Imansari, N., \& Ina S. 2017. Pengaruh Penggunaan E-Modul Interaktif Terhadap Hasil Belajar Mahasiswa pada Materi Kesehatan dan Keselamatan Kerja. Jurnal Ilmiah Pendidikan Teknik Elektro, 2(1), 1116. 


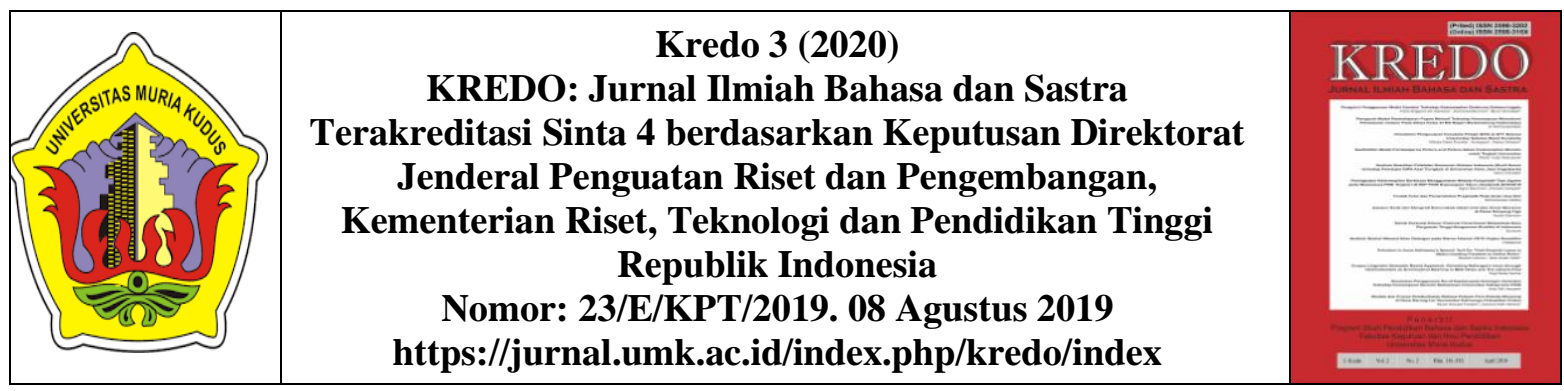

Irma, C. N. \& Ririn S. 2018. Pengembangan Bahan Ajar Mata Kuliah Berbicara dengan Metode Student Facilitator and Explaining di Universitas Peradaban. Jurnal Kredo, 2(1), 157-169.

Kristanto, A., Mustaji., \& Andi, M. 2017. The Development of Instructional Materials E-Learning Based on Blended Learning. International Education Studies, 10(7), 10-17.

Kusmiatun, A. 2016. Mengenal BIPA

(Bahasa Indonesia bagi Penutur Asing) dan Pembelajarannya.

Yogyakarta: K-Media.

Kusmiatun, A., Suyitno, I., HS, Widodo., \& Basuki, IA. 2017. Identifying Features of Indonesian for Speakers of Other Languages (BIPA) Learning for Academic Purposes. International Journal of Social Sciences \& Educational Studies, 3(4), 197-207.

Lubna, S. 2017. Penyusunan Bahan Ajar Bahasa Indonesia Bagi Penutur Asing (BIPA) untuk Pebelajar Anak. Tuah Talino, 11(1), 8394.

Maharani, T., \& Endang S. A. 2018. Pemerolehan Bahasa Kedua dan Pengajaran Bahasa dalam Pembelajaran BIPA. Jurnal Bahasa Lingua Scientia, 10(1), 121-142.

Majid, Abdul. 2008. Perencanaan
Pembelajaran:

Mengembangkan Standar Kompetensi Guru. Bandung: Remaja Rosda Karya

Ningrum, R. K., Herman J. W., \& Retno, W. 2017. BIPA (Bahasa Indonesia Penutur Asing) Sebagai Upaya Internasionalisasi Universitas di Indonesia. The1st Education Language International Conference Proceedings Center for International Language Development of Unissul, 726-732.

Prasetiyo, A. E. 2015. Pengembangan Bahan Ajar BIPA Bermuatan Budaya Jawa bagi Penutur Asing Tingkat Pemula. Skripsi. Universitas Negeri Semarang.

Prasetiyo, M. T. 2017. ICT-Based Instructional Material Development: a Study of Communication

Department Students. IJET, 6(2), 229-247.

Prastowo, A. 2018. Sumber Belajar \& Pusat Sumber Belajar Teori dan Aplikasinya di Sekolah/ Madrasah. Jakarta: Kencana

Purwaningtyas., Wasis, D. W., \& Imam, H. 2017. Pengembangan Modul Elektronik Mata Pelajaran Pendidikan Jasmani, Olahraga, dan Kesehatan Kelas XI Berbasis Online dengan Program Edmodo. Jurnal Teori, Penelitian, dan 

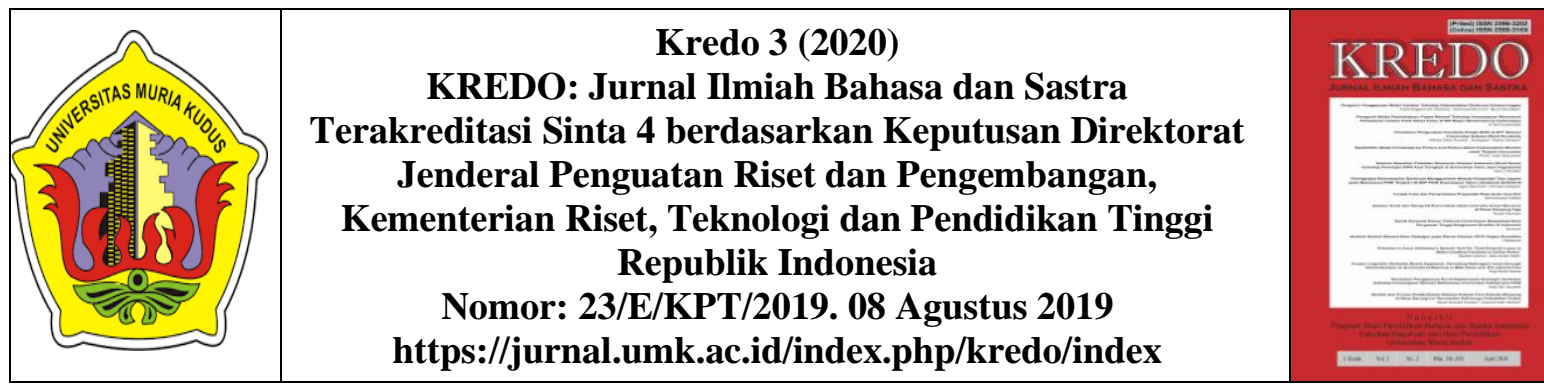

Pengembangan, 2(1), 121-129.

Purwiyanti, Y., Suwandi, S., \& Andayani. 2017. Strategi Komunikasi Pemelajar Bahasa Indonesia bagi Penutur Asing Asal Filipina. Ranah: Jurnal Kajian Bahasa, 6(2), 160-179.

Raharjo, B. W., Enny, D. L., \& Catur, K. A. P. 2018. Pengaruh Bahan Ajar Berbasis Komputer Terhadap Hail Belajar Siswa pada Mata Pelajaran Bahasa Indonesia di SMA 1 Jekulo Kudus. Jurnal Kredo, 1(2), 119-134.

Rahmawati, L. E., Suwandi, S., Saddhono, K., \& Setiawan, B. 2018. Prototype of Indonesian Reading Test for the Foreign Students. International Conference on Language, Literature, and Education (ICLLE 2018), 125-134.

Ramadhani, R., Widodo Hs, \& Titik Harsiati. 2016. Pengembangan Bahan Ajar Keterampilan Berbicara Bahasa Indonesia Bagi PenuturAsing Tingkat Pemula. Jurnal Pendidikan: Teori, Penelitian dan Pengembangan, 1(3), 326-337.

Ramliyana, R. 2019. Penggunaan Buku Komik "Bahasa Indonesia Bagi Penutur Asing (BIPA) 1" dan

Pengaruhnya Terhadap Hasil Belajar Peserta BIPA. Jurnal Bahasa Indonesia bagi Penutur Asing, 1(1), 30-40.

Samuel, W. A. 2009. The Importance of Instructural Materials in Our Schools an Overview. New Era Research Journal of Human, Educational and Sustainable Development, 2(3), 61-63.

Serdiyukov. 2017. Innovation in Education: What, Works, What Doesn't, and What to do About it?. Journal of Research in Innovative Teaching \& Learning, 10(1), 4-33.

Siroj, M. 2015. Pengembangan Model Integratif Bahan Ajar Bahasa Indonesia Ranah Sosial Budaya Berbasis ICT Bagi Penutur Asing Tingkat

Menengah. Jurnal

Pendidikan Bahasa dan Sastra Indonesia, 4(2), 74-84.

Sugiyono. 2017. Metode Penelitian Kuantitatif Kualitatif dan $R \& D$. Bandung: Alfabeta.

Suwarta, W., Agus S., \& Undang R. 2018. Development of Interactive E-Module for Global Warming to Grow Critical Thinking Skills. International Journal of Advanced Engineering, Management and Science (IJAEMS), 4(7), 543-549.

Suyitno, I., Gatut S., Musthofa K., \& Ary F. 2017. Cognitive Learning Strategy of 


Kredo 3 (2020)
KREDO: Jurnal Ilmiah Bahasa dan Sastra
Terakreditasi Sinta 4 berdasarkan Keputusan Direktorat
Jenderal Penguatan Riset dan Pengembangan,
Kementerian Riset, Teknologi dan Pendidikan Tinggi
Republik Indonesia
Nomor: 23/E/KPT/2019. 08 Agustus 2019
https://jurnal.umk.ac.id/index.php/kredo/index

BIPA Students in

Learning the Indonesia Language. IAFOR

Journal of Language

Learning, 3(2), 175-190

Tanjung, P., Syahnan D., \& Oky, F. G.

2018. The Development

of Local Wisdom of

Labuhanbatu Based on

Teaching Material of

Descriptive Text for $7^{\text {th }}$

Grade Student at SMP

Negeri 1 Bilah Barat,

Indonesia. International

Journal of Education,

Learning, and

Development,6(1) 80-92.

Ulumuddin, A., \& Agus, W. 2014.

Bahan Ajar Bahasa

Indonesia Ranah Sosial

Budaya Bagi Penutur

Asing (BIPA). Jurnal

Sasindo, 2(1), 15-35.

Umam, C. 2015. Developing

Instructional Materials of

English Morphology for

English Department

College-Learners. Journal on English as a Foreign Language, 5(1), 1-8.

Widodo, S. Chomsin., \& Jasmadi. 2008.

Panduan Penyusun Bahan Ajar

Berbasis
Kompetensi. Jakarta: Elex

Media Komputindo.

Wiratsih, W. 2019. Analisis Kesulitan

Pelafalan Konsonan

Bahasa Indonesia (Studi

Kasus Terhadap

Pemelajar BIPA Asal

Tiongkok di Universitas

Atma Jaya Yogyakarta).

Jurnal Kredo, 2(2), 242-

252.

Yahya, M., Andayani, \& Kundharu S. $2018 . \quad$ Hubungan

Penguasaan Kosakata

dengan Kesalahan Diksi

dalam Kalimat Bahasi

Indonesia Mahasiswa

BIPA Level Akademik.

Jurnal Kredo, 1(2), 53-70.

Yayang, E. 2019. Pengembangan E-

modul Berbasis Web

dengan Menggunakan

Aplikasi Moodle pada

Mata Kuliah Pengelolaan

Perpustakaan. Edutech, 18(1), 25-36.

Zabidi, N. A., Tai K. W., P. Rajesh K., Mansor F., \& Syarifah H. 2017. Quality Assurance in Learning Material Development at OUM. Asian Association of Open Universities Journal, 12(1), 69-8. 